\title{
Üstün Zekalı ve Yetenekli Öğrencilerin Bilim ve Sanat Merkezindeki ve Okuldaki Sosyal Bilgiler Dersine Yönelik Metaforik Algıları *
}

\section{The Metaphorical Perceptions of the Gifted and Talented Students towards Social Studies Lesson in the Science and Art Centre and in Their School}

\author{
Halil Bolat ${ }^{\mathrm{a}, * *}$ \\ ${ }^{a}$ Bilim Uzmanı, MEB, Adana Bilim ve Sanat Merkezi, Adana/Türkiye. \\ ORCID: 0000-0002-4726-5351
}

MAKALE BİLGISII

ÖZ

\section{Makale Geçmişi:}

Başvuru tarihi: 16 Kasım 2019

Düzeltme tarihi: 07 Mart 2020

Kabul tarihi: 19 Mart 2020

\section{Anahtar Kelimeler:}

Sosyal bilgiler

Öğrenci algısı

Üstün zekalı ve yetenekli öğrenci

\begin{abstract}
Bu araştırmanın amacı; ortaokula devam eden üstün zekalı ve yetenekli öğrencilerin bilim ve sanat merkezindeki sosyal bilgiler dersi ile okuldaki sosyal bilgiler dersine yönelik metaforik algılarını belirlemektir. Araştırma, olgu bilim olarak desenlenmiştir. Araştırma, 40 öğrenci ile yürütülmüştür. Araştırmada veri toplama aracı olarak metafor belirleme formu kullanılmıştır. Elde edilen veriler üzerinde içerik analizi yapılmıştır. Üstün zekalı ve yetenekli öğrenciler bilim ve sanat merkezindeki sosyal bilgiler dersini eğlenceli, bilgilendirici, yönlendirici ve düşünmeyi sağlayan bir ders olarak görürken, okullarındaki sosyal bilgiler dersini bilgilendirici, eğlendirici, sıkıcı ve hayata hazırlayıcı bir ders olarak görmektedirler. Öğrencilerin sosyal bilgiler dersine yönelik olumlu algılara sahip oldukları sonucuna ulaşılmıştır.
\end{abstract}

\section{A B S T R AC T}

This research aims to identify the metaphorical perceptions of the secondary school gifted and talented students towards social studies lesson in the science and art centre and in their school. This study used a phenomenological design. The research was carried out with 40 students. This research employed a metaphor determination form as a data collection tool. Content analysis was performed on the obtained data. While students consider social studies lesson in science and art center as a enjoyable, informative, guiding and thought-provoking lesson, they see the social studies lesson in their schools as an informative, entertaining, boring and life-preparing lesson. It has been determined that students have positive perceptions about the social studies lesson.

\section{Keywords:}

Social Studies

Student perception

Gifted and talented student
Türkiye'de üstün zekalı öğrencilere eğitim-öğretim imkânı, öğrencilerin devam ettikleri özel yetenekliler destek eğitim odalarında, fen liselerinde, bilim ve sanat merkezlerinde (BİLSEM) ve Araştırma Geliştirme Eğitim ve Uygulama Merkezi'nde (ARGEM) sunulmaktadır (Baykoç, 2011; Bolat, 2020; Sevgili-Koçak ve Kan, 2019). Bilim ve Sanat Merkezleri Yönergesine (2016) göre BİLSEM'lerde okul öncesi eğitimle başlayıp lise eğitimi bitene kadar devam eden bir eğitim öğretim süreci vardır. Ancak henüz okulöncesi dönemindeki öğrencilere hizmet

\footnotetext{
* Bu makale, 18-20 Mart 2019 tarihinde Adana'da düzenlenen Uluslararası Türkiye Vizyonu Kongresinde sunulmuş olan Üstün Zekâlı ve Yetenekli Öğrencilerin Sosyal Bilgiler Dersine Yönelik Algılarının Belirlenmesi adlı çalışmanın düzenlenmiş ve genişletilmiş halidir.

** Sorumlu yazar/Corresponding author

e-posta: halil.bolat@gmail.com
} 
etmemektedirler. Bu merkezlerde amaç öğrencilere bireysel yetenekleri konusunda farkındalık yaratmak ve var olan kapasitelerini en iyi şekilde kullanmalarını sağlamaktır. Öğrenciler ilkokul, ortaokul veya lise düzeyindeki okullarına devam ederken okul sonrası veya hafta sonu da BİLSEM'lere devam ederler (Bolat, 2020).

BİLSEM'lerde öğrencilere beş farklı program uygulanır. $\mathrm{Bu}$ programlar sirasıyla; uyum, destek eğitimi, bireysel yetenekleri fark ettirme (BYF), özel yetenekleri geliştirme (ÖYG) ile proje üretimi ve yönetimi programlarıdır (MEB, 2016). İlk üç programda öğrencilerin gördüğü derslerden biri de sosyal bilgiler dersidir. Aynı zamanda öğrenciler ilkokul da (4. Sinıf) ve ortaokulda $(5,6,7$. Sinıflar) sosyal bilgiler dersi görmektedirler (MEB, 2018).

Sosyal Bilgiler dersi 1992 yılında, sosyal bilimler, edebiyat ve sanatın disiplinlerarası bir yolla birleştirilmesinden oluşan ve öğrencilere vatandaşlık yeterlikleri kazandırmayı amaçlayan bir ders olarak tanımlanırken daha sonra sosyal bilim dalları (antropoloji, arkeoloji, coğrafya, din, ekonomi, felsefe, hukuk, psikoloji, siyasal bilimler, sosyoloji ve tarih) ile doğa bilimleri, matematik, edebiyat ve sanatın uygun konularından oluşan sistematik ve koordineli bir ders olarak tanımlanmıştır (NCSS, 1994). Sosyal Bilgiler dersi Wesley tarafindan sosyal bilimlerin pedagojik amaçlarla basitleştirilmiş şekli olarak tanımlanmaktadır (Phillips, 1942). Barr, Barth ve Shermis (1997) ise sosyal bilgileri "vatandaşlık eğitimi için sosyal bilimler ile beşerî bilimlerin birleşimi” olarak tanımlamışlardır. Sosyal bilgiler dersinin temel amacı da etkili ve demokratik vatandaş yetiştirmek olarak belirlenmiştir (Boyle-Baise ve Goodman, 2009; Memişoğlu, 2014; Poatob, 2015).

2018 sosyal bilgiler öğretim programı incelendiğinde programda 10 kök değer ile 18 değerin yer aldığ görülmektedir. Kök değerler; sevgi, saygı, dürüstlük, dostluk, yardımseverlik, sorumluluk, öz denetim, sabır, adalet ve vatanseverliktir. Ayrıca programda eleştirel düşünme, yenilikçi düşünme, iş birliğii, iletişim, problem çözme gibi 27 beceri ve Türkiye yeterlikler çerçevesinde belirlenmiş anadilde iletişim, öğrenmeyi öğrenme, dijital yetkinlik, kültürel farkındalık ve ifade, matematiksel yetkinlik ve bilim/teknolojide temel yetkinlikler, inisiyatif alma ve girişimcilik, sosyal ve vatandaşlıkla ilgili yetkinlikler ve yabancı dillerde iletişim olmak üzere sekiz yetkinlik yer almaktadır (MEB, 2018). Bilim ve Sanat Merkezleri yönergesine göre BİLSEM'lerde tüm eğitim programları öğrencilerin yeteneklerine uygun proje tabanlı, disiplinler arası, zenginleştirilmiş ve farklılaştırılmış bir yapıda olup etkinliklerde bu yönde hazırlanmaktadır. Sosyal bilgiler programının uygulanmasında bireysel ve grup etkinlikleri kullanılmaktadır. Program da tarihî mekân, müze, sanayi tesisi gibi okul dışı öğrenme ortamlarına da yer verilmektedir. Diğer programlar gibi sosyal bilgiler programı da problem çözme, karar verme ve yaratıcılık, üst düzey zihinsel, sosyal, kişisel ve akademik becerileri kazanmalarını sağlayacak şekilde ilgi, yetenek ve potansiyellerine göre farklılaştırılarak ve zenginleştirilerek hazırlanmaktadır. Programlar ve öğrenme öğretme etkinlikleri yaparak yaşayarak öğrenen, gerçek yaşam problemlerine çözüm üreten, yaratıcı düşünebilen, çevresi ile iletişim kurabilen, bilimsel araştırma ve buluş yapabilen bireyler olarak yetiştirilmelerini sağlayacak şekilde hazırlanmaktadır. Programda sosyal bilgiler temalarının derinlemesine ve ileri düzeyde bilgi, beceri ve davranış içermesine dikkat edilmektedir (MEB, 2019).

$\mathrm{Bu}$ araştırmanın amacı; ortaokula devam eden üstün zekalı ve yetenekli öğrencilerin BİLSEM'deki sosyal bilgiler dersi ile okullarındaki sosyal bilgiler dersine yönelik metaforik algılarını belirlemektir.

Araştırmadan elde edilen sonuçlar üstün zekalı ve yetenekli öğrencilerin BİLSEM'deki ve okuldaki sosyal bilgiler dersine yönelik algılarını ortaya koyması ve öğrencilerin sosyal bilgiler dersine yönelik algılarını somutlaştırması açısından alan yazına katkıda bulunabilir. Ayrıca öğrencilerin sosyal bilgiler dersine yönelik algıları, derse olan tutumları açısından da bilgi verebilir. Bunun yanı sıra alan yazında yapılan araştırmalarda üstün zekalı ve yetenekli öğrencilerin hem BİLSEM'deki hem de okuldaki sosyal bilgiler dersine yönelik algılarının ayrı ayrı belirlendiği bir çalışmaya rastlanmamış olması da yapılan araştırmanın önemini arttırmaktadır.

\section{Yöntem}

$\mathrm{Bu}$ bölümde sırasıyla araştırmanın desenine, çalışma grubuna, veri toplama aracına, verilerin toplanmasina ve verilerin analizine yer verilmiştir.

\subsection{Araştırma Deseni}

$\mathrm{Bu}$ çalışmada ortaokula devam eden üstün zekalı ve yetenekli öğrencilerin bilim ve sanat merkezindeki sosyal bilgiler dersi ile okuldaki sosyal bilgiler dersine yönelik metaforik algıları incelenmiştir. Araştırma, nitel araştırma yöntemlerinden olan olgu bilim deseninde tasarlanmıştır. Araştırmada sosyal bilgiler dersi olgu olarak kabul edilmiş ve bu dersi alan üstün zekalı ve yetenekli öğrencilerin hem BİLSEM'de hem de kendi okullarındaki sosyal bilgiler dersine yönelik algıları belirlenmiştir. Nitel araştırmalarda olgu bilim deseni sıklıkla kullanılan bir desen olarak karşımıza çıkmaktadır. Olgu bilim deseninde odak noktayı, günlük yaşantımızda farklı şekilde karşılaştığımız bu nedenle farkında olsak da yeterli düzeyde derinliğine ve ayrıntısına sahip olmadığımız olgular oluşturur. $\mathrm{Bu}$ çalışmada BİLSEM'e devam eden öğrencilerin sosyal bilgiler dersine yönelik algıları derinlemesine ortaya çıkartıldığından olgu bilim deseni çalışmaya uygun olarak belirlenmiştir. Olgu bilim araştırmalarında veri kaynağı ile olgu arasında bir ilişki olduğu ve olguyu yaşamış bireylerin olguyu ortaya koyabileceği belirtilmektedir (Miller, 2003).

Araştırmada öğrenci algılarını belirlemek amacıyla metaforlardan yani mecazlardan faydalanılmıştır. Nitel araştırmalarda metaforlar aracılığıyla verilerin toplanması betimleyici bir rolü oluşturur (Morgan, 1986). Bu durum olay ya da olguların olduğu gibi ortaya konulmasını sağlar, olay ya da olgular olduğu gibi resmedilir. Stearman'a 
(1985) göre ise metaforlar, olguların bir alandan başka bir alana taşınmasını sağlayarak, gerçeği süzer ve basit bir şekilde tanımlanmasını sağlar (Akt: Yıldırım ve Şimşek, 2016).

\section{2. Çalışma Grubu}

Araştırma, BİLSEM'de bireysel yetenekleri fark ettirici programa devam eden ve 5. sinıf olan 40 öğrenci ile yürütülmüştür. Araştırmada, araştırmacı tarafindan belirlenen hem ortaokula hem de BYF programına devam eden BİLSEM öğrencisi olma ölçütlerinden dolayı ölçüt örnekleme yöntemi kullanılmıştır. Ölçüt örnekleme önceden belirlenen ölçütleri karşılayan durumları çalışma, gözden geçirmedir ve seçilecek durumlardan zengin bilgi elde edilir. (Patton, 2014). Çalışma grubuna ait demografik özellikler Tablo 1'de sunulmuştur.

Tablo 1. Araştırmaya Katılan Öğrencilerin Demografik Özellikleri

\begin{tabular}{llll}
\hline & Demografik Özellik & $\mathrm{n}$ & $\%$ \\
\hline \multirow{2}{*}{ Cinsiyet } & Kız & 14 & 35 \\
& Erkek & 26 & 65 \\
\multirow{2}{*}{ Okul türü } & Devlet okulu & 18 & 45 \\
& Özel okul & 22 & 55 \\
\hline
\end{tabular}

Tablo 1'e göre araştırmaya katılan öğrencilerin 14'ü (\%35) k1z ve 26'sı (\%65) erkektir. Ayrıca öğrencilerin 18'i (\%45) devlet okuluna ve 22 'si $(\% 55)$ özel okula devam etmektedir.

\subsection{Veri Toplama Arac1}

Araştırmada veriler, metaforlar yani mecazlar yoluyla toplanmıştır. Bu amaçla veri toplama aracı olarak ilgili alan yazın taraması sonucu araştırmacı tarafından hazırlanan, metafor belirleme formu kullanılmıştır. Formun ilk bölümünde öğrencilerin cinsiyet ve okul türüne ait demografik özelliklerine yer verilmiştir. İkinci bölümünde ise araştırmaya katılan öğrencilerin BİLSEM'deki sosyal bilgiler dersine yönelik algılarını ortaya çıkarmak amacıyla "BILLSEM'deki sosyal bilgiler dersi .......... gibidir. Çünkü ........" ve "Okuldaki sosyal bilgiler dersine yönelik algılarını belirlemek amacıyla da okuldaki sosyal bilgiler dersi ........ gibidir. Çünkü ......." biçiminde eksik bırakılmış cümlelere yer verilmiştir. Form iki eğitim programları ve öğretim alan uzmanına incelettirilmiş, forma yönelik olumsuz bir görüş veya öneri bildirilmediğinden form hazırlandığı hali ile bırakılmıştır.

\subsection{Verilerin Toplanmas1}

Hazırlanan metafor belirleme formu öğrencilere dağıtılmış, öğrencilere formu nasıl dolduracakları konusunda bilgi verilmiştir. "Öğretmen mum gibidir" metaforu örnek verilerek öğrenciler metafor belirleme hakkında bilgilendirilmiştir. Son olarak öğrencilere formda yer alan eksik yerleri uygun biçimde doldurmaları istenmiştir.

\subsection{Verilerin Analizi}

Araştırmada üstün zekalı ve yetenekli öğrenciler tarafından geliştirilen metaforlar, içerik analizine tabi tutularak analiz edilmiştir. Bunun için ilk aşamada öğrencilerin okul ve BİLSEM için geliştirdikleri kırkar metafor ayrı ayrı alfabetik sıraya konulmuştur. Daha sonra bu metaforların dayanakları incelenmiş, metaforları yansıtan öğrenci sayıları (n) ve yüzdeleri (\%) hesaplanmıştır. Metaforlardan hareketle kodlar oluşturulmuş, bu kodlardan hareketle kategorilendirme çalışması yapılarak temalara ulaşılmıştır. Form aracılığıyla toplanan verilerin analizi için bir eğitim programları ve öğretim uzmanı, ikinci kodlayıcı olarak belirlenmiştir. Araştırmacı ve ikinci kodlayıcı tarafından kodlamalar yapılarak karşılaştırılmıştır. İki kodlayıcının yaptığı kodlamalarda BİLSEM sosyal bilgiler dersi için 36 kodda görüş birliği 4 kodda ise görüş ayrılığı yaşanırken okuldaki sosyal bilgiler dersi için 34 kodda görüş birliği ve 6 kodda görüş ayrılığı yaşanmıştır. Belirlenen kodlar kullanılarak Miles ve Huberman'ın güvenirlik formülü ile güvenirlik kat sayısı hesaplanmıştır. Buna göre kodlayıcılar arasındaki güvenirlik katsayısı BİLSEM sosyal bilgiler dersi için \% 90, okul sosyal bilgiler dersi için \% 85 olarak hesaplanmıştır. Hesaplama sonucunda $\% 70$ ve üzerinde sonuca ulaşılması araştırmanın güvenilir olduğunu göstermektedir (Miles ve Huberman, 2015).

\section{Bulgular}

$\mathrm{Bu}$ bölümde üstün zekalı ve yetenekli öğrencilerin BİLSEM'deki ve okuldaki sosyal bilgiler dersine yönelik oluşturdukları metaforlara ait bulgulara yer verilmiştir.

\section{Üstün zekalı ve yetenekli öğrencilerin bilsem'deki sosyal bilgiler dersine yönelik metaforik algıları}

Üstün zekalı ve yetenekli öğrencilerin BİLSEM'deki sosyal bilgiler dersine yönelik geliştirdikleri metaforlara ilişkin bulgular Tablo 2'de sunulmuştur.

Tablo 2 incelendiğinde öğrencilerin BİLSEM'deki sosyal bilgiler dersine yönelik toplam 40 metafor geliştirdikleri görülmektedir.

$\mathrm{Bu}$ metaforlardan oyun metaforu üç, parti, lunapark ve kitap metaforları iki diğer metaforlar birer defa kullanılmıştır. $\mathrm{Bu}$ metaforların mantıksal dayanaklarının analiz edilmesiyle kodlar oluşturulmuş, bu kodlar dört kategori altında sınıflandırılarak Tablo 3 'te sunulmuştur. 
Tablo 2. Öğrencilerin BİLSEM'deki Sosyal Bilgiler Dersine Yönelik Metaforları

\begin{tabular}{|c|c|c|c|c|c|c|c|c|}
\hline Metafor & f & $\%$ & Metafor & $\mathbf{f}$ & $\%$ & Metafor & f & $\%$ \\
\hline Oyun & 3 & 7,5 & Gökkuşağ 1 & 1 & 2,5 & Silgi & 1 & 2,5 \\
\hline Parti & 2 & 5 & Güneş & 1 & 2,5 & Tarih & 1 & 2,5 \\
\hline Lunapark & 2 & 5 & Harita & 1 & 2,5 & Tasarruflu Ampul & 1 & 2,5 \\
\hline Kitap & 2 & 5 & Kar & 1 & 2,5 & Tiyatro & 1 & 2,5 \\
\hline Ağaç & 1 & 2,5 & Kedi & 1 & 2,5 & Top & 1 & 2,5 \\
\hline Anaokulu & 1 & 2,5 & Komedi Program 1 & 1 & 2,5 & Toplum & 1 & 2,5 \\
\hline Anne & 1 & 2,5 & Komedyen & 1 & 2,5 & Vantilatör & 1 & 2,5 \\
\hline Ay & 1 & 2,5 & Mucit & 1 & 2,5 & Yavru Kedi & 1 & 2,5 \\
\hline Bilim İnsanı & 1 & 2,5 & Pamuk & 1 & 2,5 & Yavru Köpek & 1 & 2,5 \\
\hline Çiçek & 1 & 2,5 & Pil & 1 & 2,5 & Yeni Dünyayı Keşfetmek & 1 & 2,5 \\
\hline Ders program 1 & 1 & 2,5 & Rol & 1 & 2,5 & Zekâ Oyunu & 1 & 2,5 \\
\hline Google & 1 & 2,5 & Roller Coaster & 1 & 2,5 & & & \\
\hline
\end{tabular}

Tablo 3. BİLSEM'deki Sosyal Bilgiler Dersine Yönelik Geliştirilen Metaforların Kavramsal Kategorileri

\begin{tabular}{|c|c|c|c|}
\hline Kategoriler & Metaforlar & f & $\%$ \\
\hline Eğlendirici & $\begin{array}{l}\text { Lunapark (2), Oyun (2), Parti } \\
\text { (2), Anaokulu (1), Bilim İnsanı } \\
\text { (1), Roller Coaster (1), } \\
\text { Gökkuşağı (1), Kitap (1), } \\
\text { Komedi Programı (1), } \\
\text { Komedyen (1), Köpek (1), } \\
\text { Tiyatro (1), Top (1), Vantilatör } \\
\text { (1), Yavru Zeka Oyunu (1) }\end{array}$ & 18 & 45,0 \\
\hline Bilgilendirici & $\begin{array}{l}\text { Güneş (1), Anaokulu (1), Anne } \\
\text { (1), Ay (1), Bilim İnsanı (1), } \\
\text { Google (1), Harita (1), Kitap } \\
\text { (1), Pil (1), Rol (1), Silgi (1), } \\
\text { Tarih (1), Tasarruflu Ampul (1), } \\
\text { Yavru Kedi (1), Yeni dünyayı } \\
\text { Keşfetmek (1) }\end{array}$ & 15 & 37,5 \\
\hline Yönlendirici & $\begin{array}{l}\text { Anne (1), Ağaçlar (1), Kedi (1), } \\
\text { Rol (1) }\end{array}$ & 4 & 10,0 \\
\hline $\begin{array}{l}\text { Düşünmeyi } \\
\text { Sağlama }\end{array}$ & $\begin{array}{l}\text { Kitap (1), Komedi Programı } \\
\text { (1), Mucit (1) }\end{array}$ & 3 & 7,5 \\
\hline TOPLAM & & 40 & 100 \\
\hline
\end{tabular}

Tablo 3'e göre üstün zekalı ve yetenekli öğrencilerin BİLSEM'deki sosyal bilgiler dersine yönelik geliştirdikleri metaforlar dört kategori altında toplanmıştır. Bu metaforlar eğlendirici, bilgilendirici, yönlendirici ve düşünmeyi sağlamadır. Tabloya göre en fazla metaforun 18 metafor ile eğlendirici, 16 metafor ile bilgilendirici bir ders kategorilerinde toplandığ 1 ve iki kategorideki metaforun birbirine yakın olduğu da görülmektedir. Yönlendirici kategorisinde dört, düşünmeyi sağlama kategorisinde ise üç metafor olduğu görülmektedir.

\section{Eğlendirici bir ders olarak sosyal bilgiler kategorisi}

$\mathrm{Bu}$ kategori 18 metafordan oluşmaktadır. Bu metaforlar ve frekansları lunapark (2), oyun (2), parti (2), anaokulu (1), bilim insanı (1), gökkuşağı (1), kitap (1), komedi programı (1), komedyen (1), roller coaster (1), tiyatro (1), top (1), vantilatör (1), yavru köpek (1) ve zekâ oyunu (1) şeklindedir.

Eğlendirici bir ders olarak sosyal bilgiler kategorisinde bulunan bazı metaforik ifadeler ve gerekçeleri öğrenciler tarafından şu şekilde ifade edilmiştir:

“BILLSEM'deki sosyal bilgiler dersi gökkuşağı gibidir. Çünkü gökkuşă̆l genellikle hem de çoğu zaman ĕglencelidir. Sadece \%1 sıkıcıdır. BILSEM'de sosyal çoğu zaman eğlencelidir." (Ö1)

"BİLSEM'deki sosyal bilgiler dersi lunapark gibidir. Çünkü çok zevkli sıkllmadan işlenen bir derstir.” (Ö8)

"BILLSEM'deki sosyal bilgiler dersi parti gibidir. Çünkü eğlencelidir ve zamanın nasıl geçtiğini anlamıyorum." (Ö10)

Yukarıda verilen doğrudan alıntılarda görüldüğü gibi öğrenciler BİLSEM'deki sosyal bilgiler dersinin eğlendirici olduğunu çoğu zaman eğlencelidir, çok zevkli, sıkılmadan işlenen derstir, eğlencelidir ve zamanın nasıl geçtiğini anlamıyorum şeklinde ifade etmişlerdir.

\section{Bilgilendirici bir ders olarak sosyal bilgiler kategorisi}

$\mathrm{Bu}$ kategori on beş metafordan oluşmaktadır. Bu metaforlar ve frekansları güneş (1), anaokulu (1), anne (1), ay (1), bilim insanı (1), google (1), harita (1), kitap (1), oyun (1), pil (1), rol (1), silgi (1), tarih (1), tasarruflu ampul (1), yavru kedi (1) ve yeni dünyayı keşfetmek (1) şeklindedir.

Bilgilendirici bir ders olarak sosyal bilgiler kategorisinde bulunan bazı metaforik ifadeler ve gerekçeleri öğrenciler tarafından şu şekilde ifade edilmiştir:

"BILLSEM'deki sosyal bilgiler dersi yeni dünyayı keşfetmek gibidir. Çünkü yeni dünya keşfedildiğinde yeni bilgiler ve yeni canlllar ögrenirsin. BILLSEM'deki sosyal bilgiler dersinde de hiç bilmediğim yeni bilgiler ögrenirim." (Ö16)

"BILLSEM'deki sosyal bilgiler dersi harita gibidir. Çünkü harita göründüğ̈̈ alana bilgi verir sosyal bilgiler gibi." (Ö24) 
"BILLSEM'deki sosyal bilgiler dersi tarih gibidir. Çünkü tarih eskiden beri var ve bilgi verir. BILLSEM'deki sosyal bilgiler dersi bize eskiyi öğretir." (Ö34)

Yukarıda verilen doğrudan alıntılarda görüldüğü gibi öğrenciler BİLSEM'deki sosyal bilgiler dersinin bilgilendirici olduğunu hiç bilmediğim yeni bilgiler öğrenirim, göründüğü alana bilgi verir ve bize eskiyi öğretir diyerek dile getirmişlerdir.

\section{Yönlendirici bir ders olarak sosyal bilgiler kategorisi}

$\mathrm{Bu}$ kategori dört metafordan oluşmaktadır. $\mathrm{Bu}$ metaforlar ve frekansları anne (1), ağaçlar (1), kedi (1) ve rol (1) şeklindedir.

Yönlendirici bir ders olarak sosyal bilgiler kategorisinde bulunan bazı metaforik ifadeler ve gerekçeleri öğrenciler tarafından şu şekilde ifade edilmiştir:

“BİLSEM'deki sosyal bilgiler dersi kedi gibidir. Çünkü kedilerin gözleri karanlıkta parlar. BILLSEM'deki sosyal bilgiler dersi de cahilliğin karanlığında bizi aydınlatarak ileride ne yapacă̆ımızı söyler." (Ö13)

“BILLSEM'deki sosyal bilgiler dersi ağaçlar gibidir. Çünkü ağaçlar oksijen vererek insanların yaşamalarını sağlar. Sosyal bilgiler dersi de ögrencilere bilgi vererek onların ilerde daha iyi yaşamasını, meslek sahibi olabilmelerini sağlar." (Ö31)

Yukarıda verilen doğrudan alıntılarda görüldüğü gibi öğrenciler BİLSEM'deki sosyal bilgiler dersinin yönlendirici olduğunu; ileride ne yapacağımızı söyler ve öğrencilerin ileride daha iyi yaşamasını, meslek sahibi olmalarını sağlar ifadeleriyle ortaya koymuşlardır.
$\mathrm{Bu}$ kategori üç metafordan oluşmaktadır. Bu metaforlar kitap (1), komedi programı (1) ve mucit (1) şeklindedir.

Düşünmeyi sağlayan bir ders olarak sosyal bilgiler kategorisinde bulunan bazı metaforik ifadeler ve gerekçeleri öğrenciler tarafından şu şekilde ifade edilmiştir:

“BILSEM'deki sosyal bilgiler dersi mucit gibidir. Çünkü mucitler icat yapıp yeni şeyler çıkarırlar ve sosyal dersi de aynı icatlar gibi bizi düşündürür." (Ö12)

“BILSSEM'deki sosyal bilgiler dersi kitap gibidir. Çünkü yeni hayaller kurmamızı, düşünmemizi sağlar.” (Ö20)

Yukarıda verilen doğrudan alıntılarda görüldüğü gibi öğrenciler BİLSEM'deki sosyal bilgiler dersinin düşünmeyi sağlayan bir ders olduğunu sosyal bilgiler dersi icatlar gibi düşündürür, hayaller kurmamızı, düşünmemizi sağlar ifadeleriyle yansıtmışlardır.

\section{Üstün zekalı ve yetenekli öğrencilerin okuldaki sosyal bilgiler dersine yönelik metaforik algıları}

Üstün zekalı ve yetenekli öğrencilerin okuldaki sosyal bilgiler dersine yönelik oluşturdukları metaforlar Tablo 4'te sunulmuştur.

Tablo 4 incelendiğinde öğrencilerin okuldaki sosyal bilgiler dersine yönelik toplam 40 metafor geliştirdikleri görülmektedir.

Bu metaforlardan kitap dört, balon iki, diğer metaforlar ise birer defa kullanılmıştır. Bu metaforların dayanaklarının analiz edilmesiyle kodlar oluşturulmuş, bu kodlar dört kavramsal kategori altında sınıflandırılarak Tablo 5'te sunulmuştur.

\section{Düşünmeyi sağlayan bir ders olarak sosyal bilgiler kategorisi}

Tablo 4. Okuldaki Sosyal Bilgiler Dersine Yönelik Metaforlar

\begin{tabular}{|c|c|c|c|c|c|c|c|c|}
\hline Metafor & $\mathbf{f}$ & $\%$ & Metafor & $\mathbf{f}$ & $\%$ & Metafor & $\mathbf{f}$ & $\%$ \\
\hline Kitap & 4 & 10 & Kum saati & 1 & 2,5 & Seminer & 1 & 2,5 \\
\hline Balon & 2 & 5 & Küp & 1 & 2,5 & Sıkıcı Oyun & 1 & 2,5 \\
\hline Ağaç & 1 & 2,5 & Lunapark & 1 & 2,5 & Sorumluluk & 1 & 2,5 \\
\hline Ampul & 1 & 2,5 & Orman & 1 & 2,5 & $\mathrm{Su}$ & 1 & 2,5 \\
\hline Bilgisayar & 1 & 2,5 & Ödev & 1 & 2,5 & Tarih Öğrenmek & 1 & 2,5 \\
\hline Bir kitabın uyarlanmış filmi & 1 & 2,5 & Palyaço & 1 & 2,5 & Tiyatro & 1 & 2,5 \\
\hline Bilgili İnsan & 1 & 2,5 & Parti & 1 & 2,5 & Uç & 1 & 2,5 \\
\hline Evren & 1 & 2,5 & Plato & 1 & 2,5 & Yavru Kedi & 1 & 2,5 \\
\hline Gondol & 1 & 2,5 & Rehber & 1 & 2,5 & Yazıcı & 1 & 2,5 \\
\hline Harita & 1 & 2,5 & Renk & 1 & 2,5 & Y1lan & 1 & 2,5 \\
\hline Hiz treni & 1 & 2,5 & Rüzgâr & 1 & 2,5 & Zımpara Kâğıdı & 1 & 2,5 \\
\hline Konu anlatımlı Test Kitabı & 1 & 2,5 & Sade Hayat & 1 & 2,5 & & & \\
\hline TOPLAM & & & & & & & 40 & 100 \\
\hline
\end{tabular}


Tablo 5. Okuldaki Sosyal Bilgiler Dersine Yönelik Geliştirilen Metaforların Kavramsal Kategorileri

\begin{tabular}{llcc}
\hline Kategoriler & Metaforlar & f & \% \\
\hline & $\begin{array}{l}\text { Plato (1), Seminer (1), Ampul (1), } \\
\text { Sade Hayat (1), Balon (2), film } \\
\text { (1), Bilgisayar (1), Uç (1), Test }\end{array}$ & & \\
Bilgilendirici & $\begin{array}{l}\text { kitabı (1), Ağaç (1), Bilgili insan } \\
\text { (1), Sorumluluk (1), Tiyatro (1), }\end{array}$ & \\
& Harita (1), Orman (1) & & \\
& Su (2), Kitap (2), Hız treni (1), & 11 & 27,5 \\
Eğlenceli & $\begin{array}{l}\text { Gondol (1), Lunapark (1), Palyaço } \\
\text { (1) Parti (1), Renk (1), Yavru Kedi }\end{array}$ & & \\
& (1), & & \\
& Evren (1), küp (1), Ödev (1), Kum & 9 & 22,5 \\
Sıkıcı & saati (1), Yavru Kedi (1), Kitap & & \\
& (1), Tarih öğrenmek (1), Yazıcı & & \\
& (1), Sikıcı oyun (1) & & \\
Hayata & Rehber (1), Kitap (1), Rüzgâr (1), & 4 & 10 \\
hazırlayıcı & Zımpara kâğıdı (1) & & \\
\hline TOPLAM & & 40 & 100 \\
\hline
\end{tabular}

Tablo 5 incelendiğinde üstün zekalı ve yetenekli öğrencilerin okuldaki sosyal bilgiler dersine yönelik geliştirdikleri metaforlar dört kategori altında toplanmıştır. Bunlar bilgilendirici, eğlendirici, sıkıcı ve hayata hazırlayıcı kategorileridir. Tabloya göre en fazla metaforun 16 metaforla bilgilendirici kategorisinde toplandığ görülmektedir. Eğlenceli kategorisinde 11, sıkıc1 kategorisinde ise dokuz metafor yer almakta iken en az metaforun dört metafor sayısı ile hayata hazırlayıcı kategorisinde yer aldığı görülmektedir.

\section{Bilgilendirici bir ders olarak sosyal bilgiler kategorisi}

$\mathrm{Bu}$ kategori on altı metafordan oluşmaktadır. Bu metaforlar balon (2), plato (1), seminer (1), ampul (1), sade hayat (1), film (1), bilgisayar (1), uç (1), test kitabı (1), ağaç (1), bilgili insan (1), sorumluluk (1), tiyatro (1), harita (1) ve orman (1) şeklindedir.

Bilgilendirici bir ders olarak sosyal bilgiler kategorisinde bulunan bazı metaforik ifadeler ve gerekçeleri öğrenciler tarafından şu şekilde ifade edilmiştir:

"Okuldaki sosyal bilgiler dersi seminer gibidir. Çünkü hocamı sadece konuşur. Ve bize sonsuz bilgi verir." (Ö6)

"Okuldaki sosyal bilgiler dersi ă̆aç gibidir. Çünkü ă̆aç dersimiz, dallarl üniteler, yapraklar konular, meyveleri de edindiğimiz bilgileri simgeler." (Ö29)

“Okuldaki sosyal bilgiler dersi harita gibidir. Çünkü harita karmaşıkmış gibi görünüyor olsa da birçok bilgiyi içerir. Okuldaki sosyal bilgiler dersindeki konular da her ne kadar karmaşık görünse de birçok bilgiyi içerir." (Ö35)

Yukarıda verilen doğrudan alıntılarda görüldüğü gibi öğrenciler okuldaki sosyal bilgiler dersinin bilgilendirici olduğunu; hocamız bize bilgi verir, ağacın yaprakları gibi bilgiye sahiptir ve karmaşık görünse de birçok bilgiyi içerir ifadeleriyle ortaya koymuşlardır.

\section{Eğlendirici bir ders olarak sosyal bilgiler kategorisi}

Bu kategori on bir metafordan oluşmaktadır. Bu metaforlar kitap (2), su (2), gondol (1), hız treni (1), parti (1), renk (1), yavru kedi (1), lunapark (1), ve palyaço (1) şeklindedir.

Eğlendirici bir ders olarak sosyal bilgiler kategorisinde bulunan bazı metaforik ifadeler ve gerekçeleri aşağıda verilmiştir:

"Okuldaki sosyal bilgiler dersi gondol gibidir. Çünkü sosyal bilgiler dersini ĕglenerek geçiririz, gondolda da eğlenerek geçiririz." (Ö2)

“Okuldaki sosyal bilgiler dersi palyaço gibidir. Çünkü ders palyaço eğlendirir. $O$ sosyal bilgiler dersi de bizi eğlendirir." (Ö38)

"Okuldaki sosyal bilgiler dersi su gibidir. Çünkü ders su gibi akıp gidiyor. Bir de çok eğlencelidir.” (Ö39)

Yukarıda verilen doğrudan alıntılarda görüldüğü gibi ögrenciler okuldaki sosyal bilgiler dersinin eğlendirici olduğunu; gondol gibi eğlencelidir, palyaço gibi eğlendirir ve su gibi eğlenceli geçer diyerek dile getirmişlerdir.

\section{Sıkıcı bir ders olarak sosyal bilgiler kategorisi}

$\mathrm{Bu}$ kategori dokuz metafordan oluşmaktadır. Bu metaforlar evren (1), küp (1), ödev (1), kum saati (1), yavru kedi (1), kitap (1),tarih öğrenmek (1), yazıcı (1) ve sıkıcı oyun (1) şeklindedir.

S1kıcı bir ders olarak sosyal bilgiler kategorisinde bulunan bazı metaforik ifadeler ve gerekçeleri aşağıda verilmiştir:

"Okuldaki sosyal bilgiler dersi Tarih öğrenmek gibidir. Çünkü çok sıkıcı ve uzuun uzuun anlatılır.” (Ö10).

"Okuldaki sosyal bilgiler dersi kum saati gibidir. Çünkü ikisinde de beklerim ve beklerken sikılırım." (Ö12)

“Okuldaki sosyal bilgiler dersi yazıcı gibidir. Çünkü ders yazıcının yavaş yazması gibi zor geçer.” (Ö39)

Yukarıda verilen doğrudan alıntılarda görüldüğü gibi öğrenciler okuldaki sosyal bilgiler dersinin sıkıcı bir ders olduğunu; çok sıkıcı ve uzun uzun anlatılır, derste sıkılırım ve ders zor geçer diyerek ifade etmişlerdir.

\section{Hayata hazırlayan bir ders olarak sosyal bilgiler kategorisi}

$\mathrm{Bu}$ kategori dört metafordan oluşmaktadır. Bu metaforlar rehber (1), kitap (1), rüzgâr (1) ve zımpara kâğıdı (1) şeklindedir.

Hayata hazırlayan bir ders olarak sosyal bilgiler kategorisinde bulunan bazı metaforik ifadeler ve gerekçeleri aşağıda verilmiştir: 
"Okuldaki sosyal bilgiler dersi rehber gibidir. Çünkü hayatımızda yapmamı gereken şeyleri ögretiyor.” (Ö15)

"Okuldaki sosyal bilgiler dersi zımpara kâğıdl gibidir. Çünkü zımpara kâğıdı tahtadaki pürüzleri yok eder. Sosyal bilgiler ise insanların kötü yönlerini yok eder. Evde, okulda, sinıfta nasıl davranmamı gerektiğini öğretir." (Ö33)

Yukarıda verilen doğrudan alıntılarda görüldüğü gibi öğrenciler okuldaki sosyal bilgiler dersinin hayata hazırlayan bir ders olduğunu; hayatımızda yapmamız gerekenleri öğretir, evde, okulda, sınıfta nasıl davranmamız gerektiğini öğretir diyerek dile getirmişlerdir.

\section{Sonuç, Tartışma ve Öneriler}

Üstün zekalı ve yetenekli ögrencilerin bilim ve sanat merkezindeki ve okuldaki sosyal bilgiler dersine yönelik algılarının belirlendiği bu araştırmada öğrencilerin hem BİLSEM'deki hem de okuldaki sosyal bilgiler dersine yönelik olumlu algılara sahip oldukları sonucuna ulaşılmıştır. Elde edilen sonuçlara göre üstün zekalı ve yetenekli öğrenciler BİLSEM_deki sosyal bilgiler dersini eğlenceli, bilgilendirici, yönlendirici ve düşünmeyi sağlayan bir ders olarak görürken, okullarındaki sosyal bilgiler dersini bilgilendirici, eğlendirici, sıkıcı ve hayata hazırlayıcı bir ders olarak görmektedirler.

Araştırma sonucunda öğrencilerin BİLSEM'deki sosyal bilgiler dersini eğlenceli, bilgilendirici, yönlendirici ve düşünmeyi sağlayan bir ders olarak görmelerinin bir nedeni derste kullanılan farklı yöntem teknikler olabilir. Kazu ve Şenol'un (2011) yaptığı araştırmada BİLSEM'lerde beyin firtınası, drama, proje tabanlı öğrenme, soru cevap, tartışma gibi öğrenci merkezli yöntem tekniklerin kullanıldığı sonucuna ulaşılmıştır. Bu yöntem tekniklerin öğrencileri süreçte aktif kıldığı, üst düzey düşünme becerilerine katkı sağlayarak derse olan olumlu tutumlarını etkilediği söylenebilir. Sibiri’ye (2017) göre farklı yöntem tekniklerin kullanılması derse yönelik olumlu tutumlar oluşmasını sağlar. Conklin ve Frei (2016) ile Mertol'a (2015) göre de üstün zekâlı ve yetenekli çocukların eğitiminde etkileşimli, eleştirel ve yaratıcı düşünme becerilerinin kazandırılmasına yardımcı olan yöntem ve teknikler daha etkili sonuçlar vermektedir. Ayrıca BIILSEM'lerin bu yöntem tekniklerin uygulanması için uygun ortamlar olduğu söylenebilir. Çünkü BİLSEM'lerde öğrenciler küçük gruplar halinde atölyelere alınmaktadır. Atölyelerde öğrenci sayısının az olması, bu yöntem tekniklerin kalabalık gruplarda kullanılmasında yaşanan sorunları en aza indirdiği söylenebilir.

Ayrıca buna bağlı olarak BİLSEM'lerde zenginleştirilmiş etkinliklerin ve proje tabanlı öğretimin kullanılması da öğrencilerin bu olumlu görüşlerinde etkili olmuş olabilir. Zenginleştirme uygulamaları öğrenciler üzerinde olumlu etkiler yapmakta, akademik başarılarını yükseltmekte, duyuşsal gelişimini ve motivasyonlarını arttırmaktadır. Ayrıca öğrencilere, tercih ettikleri konuları derinlemesine çalışma imkânı da sunmaktadır (Davis, 2014; Saranlı, 2017).

Üstün zekalı ve yetenekli öğrencilerin sosyal bilgiler dersine yönelik yapılan farklı araştırmalarda da benzer sonuçlara ulaşılmıştır. Bolat (2018) tarafindan yapılan araştırmada üstün zekalı ve yetenekli öğrencilerin sosyal bilgiler dersini gerçek yaşamı yansıtan, geniş bir kapsama ve içeriğe sahip, bilgilendirici bir ders olarak algıladıkları sonucuna ulaşılmıştır. Mertol, Doğdu ve Yılar (2013), tarafindan yapılan araştırmada üstün zekâlı ve yetenekli öğrencilerin sosyal bilgiler dersine yönelik algıları metaforlar yoluyla incelenmiş ve öğrenciler sosyal bilgiler dersini gerçek yaşam becerileri kazandıran bir ders olarak ifade etmişlerdir. Bunun yanı sıra öğrenciler sosyal bilgiler dersinin önemli ve gerekli bir ders olduğuna inandıklarını da ortaya koymuşlardır.

Araştırmada elde edilen sonuçlara göre üstün zekalı ve yetenekli öğrenciler okuldaki sosyal bilgiler dersini bilgilendirici, eğlenceli ve hayata hazırlayıcı bir ders olarak görmüşlerdir. $\mathrm{Bu}$ sonuçlar öğrencilerin sosyal bilgiler dersine yönelik olumlu tutumlara sahip olduklarını göstermektedir. Araştırmada ulaşılan sonuçlar alan yazındaki araştırmalarla paralellik göstermektedir (Akengin, Bengiç, Çolak ve Taş, 2011; Akengin ve Kafadar, 2016; Çelebi, 2006; Çetin ve Dinç, 2017; Gömleksiz, Kan ve Öner, 2012; Khaled, 2013; Ocak ve Didin, 2018; Okon ve Archibong, 2014; Sibiri, 2017; Thiveos, 2000; Tural, 2015; Yaşar ve Bayır, 2010). Araştırmada elde edilen bu sonuçların farklı nedenleri olabilir. $\mathrm{Bu}$ nedenler arasinda 2005 yilinda yapilan değiş̧iklikle yapılandırmacı eğitime geçilmesi, buna bağlı olarak öğrenci merkezli yöntem tekniklerin çeşitliliğinin artması, ders içeriğinin gerçek yaşamla bağlantılı olması ve FATİH projesi ile etkileşimli tahtaların kullanılmaya başlanması sayılabilir.

Sosyal bilgiler dersinde yapılandırmacı eğitime geçilmesi ile kullanılan yöntem teknikler öğrenci merkezli hale gelmiş̧ir (Ay, 2018; Ocak ve Didin, 2018; Ocak ve Yurtseven, 2009). Şahin ve Güven (2016) tarafindan yapılan araştırmada öğretmenlerin hayat bilgisi ve fen bilimleri derslerinde olduğu gibi sosyal bilgiler dersinde de anlatım, gösteri, soru cevap, drama, balık kılçığı, beyin firtınası, örnek olay ve altı şapkalı düşünme tekniği gibi yöntem ve teknikleri kullandıkları sonucuna ulaşılmıştır. Öğrenci merkezli öğretimde öğrencilerin ilgileri, ihtiyaçları, yetenekleri, özellikleri, değerleri ve becerileri ile farklı yöntem, teknik ve stratejilerin kullanımı önemli görülmektedir (Jackson, 2006; Akt: Tural, 2015; Larasati, 2018; Ocak ve Yurtseven, 2009; Oliva ve Gordon, 2018; Ornstein ve Hunkins, 2016; Öntaş, 2014; Tural, 2015). Bu durum öğrencilerin derste aktif olmalarını sağlamış, öğrenciler dersten zevk almış ve öğrencilerin derse karşı olumlu tutumları artmıştır (Avcı-Yavuz, 2009; Ocak ve Didin, 2018). Ayrıca yapılandırmacı eğitim ile öğrencilerin bilgiyi keşfetmesi sağlanmış ve bilgilerin kalıcılığı da artmıştır. Yapılandırmacı eğitim ile sosyal bilgiler dersinin içeriği günlük yaşamla daha çok ilişkilendirilmiş̧ir (Ay, 
2018; Çalışkan, 2015; Erdoğan, 2009; Şahin-Yanpar, 2001). Bu nedenle yapılandırmacı eğitimin öğrencilerin sosyal bilgiler dersine yönelik olumlu tutumlara sahip olmaları üzerinde etkili olduğu söylenebilir.

Öğrencilerin iyi bir eğitim alması, kaliteli içeriklerin sunulması ve eğitimde firsat eşitliğini sağlamak amacıyla başlatılmış olan FATİH projesi ile okullarda etkileşimli tahta kullanılmasına geçilmiştir. Etkileşimli tahtalar ile öğretmen ve öğrencilerin Eğitim Bilişim Ağı'na (EBA) ulaşmaları, güncel, zengin ve eğitici içerikleri kullanmaları ve farklı öğrenme stillerine sahip öğrencilere hitap etme imkânı sağlanmıştır (Karakaş ve Doğan, 2017; MEB, 2019). Bu durum, öğrencilerin sosyal bilgiler dersine ve farklı disiplinlere karşı olumlu tutumlar geliştirmelerini sağlamıştır (Çalışkan ve Altundaş, 2016; Demircioğlu ve Demircioğlu, 2015; Gündüz ve Çelik, 2015; Kaya ve Aydın, 2011; Koçak, 2013; Sayır, 2014; Türkoğlu, 2014; Yolcu ve Bayram, 2016; Yorgancı ve Terzioğlu, 2013).

Araştırma sonucunda elde edilen tek olumsuz sonucun öğrencilerin okuldaki sosyal bilgiler dersini sıkıcı bulmalarıdır. Rodriguez (2019) ve Zhao ve Hoge (2005) tarafindan yapılan araştırmalarda da benzer sonuca ulaşılmış, ilköğretim öğrencileri sosyal bilgiler dersine yönelik olumlu tutumlara sahip olmadıklarını, sıkıcı ve yararı olmayan bir ders olarak gördüklerini belirtmişlerdir. Öğrencilerin okuldaki sosyal bilgiler dersini sıkıcı bulmaları, sınıfların kalabalık olmasından, bunun sınıf yönetimini zorlaştırmasından ve aktif öğretim yöntem tekniklerinin kullanılmamasından kaynaklandığı söylenebilir. Van Den Heever (1997) ve Yaman'a (2010) göre bazı öğretmenler, sınıfların kalabalık olmasından dolayı öğrenciler üzerinde baskı kurabilmekte ve geleneksel yöntemleri kullanabilmektedir. Bu durum öğrenme öğretme ortamını ve öğrencileri olumsuz etkileyebilmektedir. Demirkan ve Saraçoğlu (2016), Hussain, Ahmad, Hakim (2017) ve Memişoğlu ve Köylü (2015) tarafından yapılan araştırmalarda sınıf mevcudunun kalabalık olmasından dolayı farklı yöntem tekniklerden yararlanılamadığı sonucuna ulaşılmıştır. Öğrencilerin sosyal bilgiler dersini sıkıcı bulmalarının bir başka sebebi ise sınav odaklı bir eğitimin yapılması ve sosyal bilgiler dersine yönelik önyargılar olabilir. Gönenç ve Açıkalın (2017) yaptıkları çalışmada sınav odaklı bakış açısı, derse verilen değerin düşük olması ve derse olan önyargının öğrencilerin derste sıkılmalarına neden olduğu sonucuna ulaşmışlardır. Bu da kalabalık sınıf mevcutlarının öğrenci merkezli yöntem tekniklerin kullanımını zorlaştırdığını ve öğrencilerin derse yönelik algılarını olumsuz etkilediğini göstermektedir.

Araştırma sonucunda aşağıdaki önerilerde bulunulabilir.

(i) Öğrencilerin okuldaki sosyal bilgiler dersine yönelik olumlu görüşlerinin yanı sıra sıkıcı olarak da görmelerinden hareketle, okullardaki sosyal bilgiler etkinlikleri daha eğlenceli ve öğrencilerin ilgilerini çekecek hale getirilebilir. Bunun için etkinliklerde öğrenci merkezli öğretim yöntem ve tekniklerine daha çok yer verilebilir. (ii) $\mathrm{Bu}$ araştırmada üstün zekâlı ve yetenekli öğrencilerin BİLSEM'deki ve okuldaki sosyal bilgiler dersine yönelik algıları metaforlar aracılığıyla ortaya çıkarılmıştır. Öğrencilerin sosyal bilgiler dersine yönelik algılarının belirlenmesi için görüşme, gözlem gibi farklı araştırma yöntemlerinden ayrı ayrı veya çoklu yöntem olarak birlikte yararlanılabilir.

(iii) Öğrencilerin farklı derslerle ilgili algıları belirlenerek, algılarının derslere göre karşılaştırması yapılabilir.

\section{Kaynakça}

Akengin, H., Bengiç, G., Çolak, K. ve Taş, E. (2011). Altıncı sınıf sosyal bilgiler dersi kazanımlarına ulaşma düzeylerine yönelik öğrenci görüşleri. M.Ü. Atatürk Eğitim Fakültesi Eğitim Bilimleri Dergisi, (34), 5-23.

Akengin, H. ve Kafadar, T. (2016). 6 ve 7. sinif öğrencilerinin sosyal bilgiler kavramına ilişkin metaforlar1. International Journal of Field Education, 2(1), 33-50.

Avc1-Yavuz, E. (2009). Ilköğretim beşinci sinıf sosyal bilgiler dersinde oluşturmacı öğrenme yaklaşımının ögrencilerin başarl düzeylerine ve derse yönelik tutumlarına etkisi. (Yayımlanmamış yüksek lisans tezi). Uludağ Üniversitesi Sosyal Bilimler Enstitüsü, Bursa.

Ay, A. (2018). Sosyal bilgiler ögretim programında ögrenme amaçll yazma etkinliklerinden mektup ve şiir kullanımının öğrenci başarısına etkisi. (Yayımlanmamış doktora tezi). Erzincan Üniversitesi Sosyal Bilimler Enstitüsü, Erzincan.

Barr, R., Barth, J. L. ve Shermis, S. S. (2013). Sosyal bilgilerin doğast. (C.Dönmez, Çeviri Ed.). Ankara: Pegem Akademi.

Baykoç-Dönmez, N. (2011). Özel gereksinimli çocuklar ve özel eğitim. Ankara: Eğiten Kitap.

Bolat, H. (2020). Üstün zekalı ve yetenekli öğrencilere açılan kapı: bilim ve sanat merkezleri. A. Çoban (Ed), Ĕgitim araştırmaları, içinde (s.66-78). Ankara: İksad Yayınevi.

Bolat, Y. (2018). An investigation on metaphorical conceptions of the gifted students towards social studies lesson, social studies teacher and science and art center. Journal for the Education of Gifted Young Scientists, 6(4), 17-35.

Boyle-Baise, L. ve Goodman, J. (2009) The Influence of Harold O. Rugg: Conceptual and pedagogical considerations. Social Studies, 100(1), 31-40.

Conklin, W. ve Frei, S. (2016). Üstün zekall ve yetenekliler için eğitim programının farklılaştırılması. (N. G. Kahveci, Çeviri). İstanbul: Özgür Yayınları. 
Çalışkan, H. (2015). Sosyal bilgiler öğretmenlerinin yapılandırmacı öğrenme ortamlarını düzenleme düzeylerinin çeşitli değişkenlere göre incelenmesi. Journal of Social Studies Education Research, 6(1), 49-83.

Çalışkan, H. ve Altundaş, B. (2016). Öğrencilerin sosyal bilgiler derslerinde akıllı tahta kullanımına yönelik tutumlarının incelenmesi. V. Uluslararası Sosyal Bilgiler Eğitimi Sempozyumu. Bildiri Kitabı, 28-30 Nisan 2016, Denizli.

Çelebi, C. (2006). Yapılandırmacılık yaklaşımına dayalı işbirlikli ögrenmenin ilköğretim 5. sinıf sosyal bilgiler dersinde ögrencilerin erişi ve tutumlarına etkisi. (Yayımlanmamış yüksek lisans tezi). Selçuk Üniversitesi Sosyal Bilimler Enstitüsü, Konya.

Çetin, Ş. ve Dinç, E. (2017). Ortaokul yedinci sınıf öğrencilerinin sosyal bilgiler algılarının incelenmesi. Diyalektolog Ulusal Sosyal Bilimler Dergisi, Klş(16), 241-259.

Davis, G. A. (2014). Üstün yetenekli çocuklar ve eğitimi. (M. Işık Koç Çeviri). İstanbul: Özgür Yayınları.

Demircioğlu, G. ve Demircioğlu, H. (2015). Öğrencilerin kimya derslerinde akıllı tahta kullanımına yönelik tutumlarının farklı değişkenler açısından incelenmesi. Eğitim ve Öğretim Araştırmaları Dergisi, 4(2), 387395.

Demirkan, Ö. ve Saraçoğlu, G. (2016). Anadolu lisesi öğretmenlerinin derslerde kullandıkları öğretim yöntem ve tekniklerine ilişkin görüşleri. The Journal of International Lingual, Social and Educational Sciences, 2(1), 1-11.

Erdoğan, M. (2009). Yapılandırmacı yaklaşıma göre tasarlanmış sosyal bilgiler sınıfina ilişkin öğrenci görüşlerinin incelenmesi. (Yayımlanmamış yüksek lisans tezi). Beykent Üniversitesi Sosyal Bilimler Enstitüsü, Ankara.

Gömleksiz, M. N., Kan, A. Ü. ve Öner, Ü. (2012). İlköğretim öğrencilerinin sosyal bilgiler dersine ilişkin metaforik algıları. Erzincan Üniversitesi Ĕgitim Fakültesi Dergisi, 14(2), 419-436.

Gönenç, S. ve Açıkalın, M. (2017). Sosyal bilgiler öğretmenlerinin sosyal bilgiler öğretiminde karşılaştıkları sorunlar ve bunlara getirdikleri çözüm önerileri. Trakya Üniversitesi Eğitim Fakültesi Dergisi, 7(1), 26-41.

Gündüz, S. ve Çelik, H. C. (2015). Öğrencilerin matematik dersinde akıllı tahta kullanımına yönelik tutumlarının çeşitli değişkenler açısından incelenmesi. Dicle Üniversitesi Ziya Gökalp Eğitim Fakültesi Dergisi, 25, 157-174.

Hussain, S., Ahmad, N. ve Hakim, A. F. (2017). An investigation of teaching methodologies and disciplinary problems in overcrowded classrooms. Haripur Journal of Educational Research, 1(1), 5362.

Karakaş, H. ve Doğan, A. (2017). Sınıf öğretmenlerinin sınıfta kullandıkları bilgi iletişim teknolojilerine yönelik olumsuz tutumları ve yaşadıkları sorunlar.
Hitit Üniversitesi Sosyal Bilimler Enstitüsü Dergisi, 10(1), 629-654.

Kaya, H. ve Aydın, F. (2011). Sosyal bilgiler dersindeki coğrafya konularının öğretiminde akıllı tahta uygulamalarına ilişkin öğrenci görüşleri. Journal of World of Turks, 3(1), 179-189.

Kazu, İ. Y. ve Şenol, C. (2011). Üstün yetenekliler eğitim programlarına ilişkin öğretmen görüşleri (BİLSEM örneği). e-Uluslararası Eğitim Araştırmaları Dergisi 3(2), 13-35.

Khaled, A. F. (2013). Jordanian students attitudes toward social studies education. The Journal of International Social Research, 6(24), 227-236.

Koçak, Ö. (2013). FATİH projesi kapsamındaki LCD panel etkileşimli tahta uygulamalarına yönelik öğretmen tutumları (Erzincan ili örneği). (Yayımlanmamış yüksek lisans tezi). Atatürk Üniversitesi Eğitim Bilimleri Enstitüsü, Erzurum.

Larasati, F. (2018). Student centered learnıng: an approach to develop speakıng skill in efl classroom. English Community Journal, 2(1), 153-157.

Memişoğlu, H. (2014). Sosyal bilgiler öğretmenlerinin görüşlerine göre vatandaşlık eğitimi. Turkish Studies, 9(5), 1565-1584.

Memişoğlu, H. ve Köylü, G. (2015). Sosyal bilgiler dersindeki sorunlar ve çözüm yollarına ilişkin sosyal bilgiler öğretmenlerinin görüşleri. Turkish Studies, 10(11), 1099-1120.

Mertol, H., Doğdu, M. ve Yılar, B. (2013). Üstün zekâlı ve yetenekli öğrencilerin sosyal bilgiler dersine ilişkin metaforik algıları. Üstün Yetenekli Eğitimi Araştırmaları Dergisi, 1(3), 176-183.

Mertol, H. (2015). Üstün yetenekli çocuklarda sosyal bilgiler eğitimi. F Şahin (Ed), Üstün zekall ve yetenekli ögrencilerin ĕgitimi, içinde (s.114-125). Ankara: Pegem Akademi.

MEB (2016). TC. Millî Eğitim Bakanlığı bilim ve sanat merkezleri yönergesi. https://orgm.meb.gov.tr/meb_iys_dosyalar/2016_10/0 7031350_bilsem_yonergesi.pdf_adresinden 12.02.2019 tarihinde edinilmiştir.

MEB (2018). Sosyal bilgiler dersi öğretim program1. https://docs.google.com/viewer?url=http\%3A\%2F\%2 Fmufredat.meb.gov.tr\%2FDosyalar\%2F20181210384 7686SOSYAL\%2520B\%25C4\%25B0LG\%25C4\%25 B0LER\%2520\%25C3\%2596\%25C4\%259ERET\%25 C4\%25B0M\%2520PROGRAMI\%2520.pdf adresinden 12.02.2019 tarihinde edinilmiştir.

MEB (2019). Fatih projesi kapsam. http://fatihprojesi.meb.gov.tr/about.html adresinden 13.11.2019 tarihinde edinilmiştir.

Miles, A. M. ve Huberman, M. B. (2015). Nitel veri analizi. (S. Akbaba Altun ve A. Ersoy, Çeviri Ed.) Ankara: Pegem Akademi. 
Miller, S. (2003). Analysis of phenomenological data generated with children as research participants. Nurse Researcher, 10(4), 68-82.

Morgan, G. (1986). Images of Organization. London: SAGE.

NCSS (1994). National curriculum standards for social studies: introduction. https://www.socialstudies.org/standards/introduction adresinden 12.02.2019 tarihinde edinilmiştir.

Ocak, G. ve Didin, M. (2018). Öğrencilerin yapılandırmacı sosyal bilgiler öğrenme öğretme sürecine yönelik görüşleri ile sosyal bilgiler dersine yönelik tutumları arasındaki ilişki. Karaelmas Journal of Educational Sciences 6, 1-14.

Ocak, G. ve Yurtseven, R. (2009). Beşinci sınıf sosyal bilgiler ders kitaplarının yapılandırmacı öğrenme yaklaşımına göre değerlendirilmesi. Balıkesir Üniversitesi Sosyal Bilimler Enstitüsü Dergisi, 12(22), 94-109.

Okon, C. ve Archibong, U. (2014). Teachers' attitudes to social studies and students' academic performance in junior secondary three-certificate examination. Asian Journal of Social Sciences \& Humanities, 3(3), 44-48.

Oliva, P. F. ve Gordon, W. R. (2018). Program geliştirme. (K. Gündoğdu, Çeviri Ed.). Ankara: Pegem Akademi

Ornstein, A. C. ve Hunkins, F. P. ( 2016). Eğitim programı. (A. Arı, Çeviri. Ed.). Konya: Eğitim Yayınevi.

Öntaş, T. (2014). İlköğretim sosyal bilgiler dersinde yapılandırmacı yaklaşım ile dizgeli eğitimin öğrenci erişisine etkisi arasındaki fark. Anadolu Ĕgitim Liderliği ve Öğretim Dergisi, 2(2), 43-51.

Patton, M. Q. (2014). Nitel araştırma ve değerlendirme yöntemleri. (M. Bütün ve S. B. Demir, Çeviri Ed.). Ankara: Pegem Akademi.

Phillips, B. W. (1942). Teaching the social studies by Edgar B. Wesley. The Mississippi Valley Historical Review, 29(2), 242-244.

Poatob, S. (2015). Understanding the goal of social studies: A step to the effective teaching of the subject. Research on Humanities and Social Sciences, 5(8), 182-193.

Rodriguez, J. (2019). Perceptions and practices of U.S. preservice special education teachers on teaching social studies instruction in inclusive classrooms. International Journal of Inclusive Education, 3, 1-16. doi: 10.1080/13603116.2019.1590472

Saranlı, A. G. (2017). Okul öncesi dönemdeki erken müdahale uygulamalarına farklı bir bakış: üstün yetenekli çocuklar için erken zenginleştirme. Ĕgitim ve Bilim, 42(190), 343-359.

Sayır, M. F. (2014). Fatih projesi kapsamında kullanılan akıllı tahtalara karşı öğretmen ve ögrenci tutumları ve akıllı tahtaların konuşma becerisi üzerindeki etkisi.
(Yayımlanmamış yüksek lisans tezi). Çağ Üniversitesi, Sosyal Bilimler Enstitüsü, Mersin.

Sevgili-Koçak, S. ve Kan, A. (2019). Annelerin üstün yetenekli çocuklarının özelliklerine yönelik görüşlerinin incelenmesi. Uluslararast Sosyal Araştırmalar Dergisi, 12(66), 912-923.

Sibiri, J. K. (2017). An evaluation of the impact of students' attitude towards the learning of social studies in senior high schools: A case study in the upper west region. Imperial Journal of Interdisciplinary Research, 3(3), 1528-1536.

Şahin, D. ve Güven S. (2016). Sinıf öğretmenlerinin fen bilimleri hayat bilgisi ve sosyal bilgiler derslerindeki yöntem ve teknik kullanımına ilişkin görüşleri. Online Fen Eğitimi Dergisi, 1(1), 42-59.

Şahin-Yanpar, T. (2001). Oluşturmacı yaklaşımın sosyal bilgiler dersinde bilişsel ve duyuşsal öğrenmeye etkisi. Kuram ve Uygulamada Eğitim Bilimleri, 1(2). 46- 82.

Thiveos, E. (2000). Lower secondary student attitudes towards social studies in a catholic school. (Unpublished thesis of honor). Cowan Universty, Australia.

Tural, A. (2015). Yapılandırmacı yaklaşımı benimseyen sosyal bilgiler dersi öğretim sürecine ilişkin öğrenci görüşleri. Türkiye Sosyal Araştırmalar Dergisi, 19(2), 29-40.

Türkoğlu, T. (2014). Fen ve teknoloji ögrretiminde akıll tahta kullanımının 6.sınıf ögrencilerinin akademik başarl, tutum ve görüşleri üzerine etkileri. (Yayımlanmamış yüksek lisans tezi). Celal Bayar Üniversitesi Eğitim Bilimleri Enstitüsü, Manisa.

Van Den Heever, S. (1997). Strategies for large class teaching. (Yayımlanmamış yüksek lisans tezi). University Of South Africa, South Africa.

Yaman, E. (2010). Kalabalık sınıfların etkileri: öğrenciler ne düşünüyor?. Kastamonu Eğitim Dergisi, 18(2), 403-414.

Yaşar, Ş. ve Bayır, Ö.G.( 2010) İlköğretim 5. sınıf öğrencilerinin bakış açısıyla sosyal bilgiler. e-Journal Of New World Sciences Academy, 5(3), 1213-1225.

Yıldırım, A. ve Şimşek, H. (2016). Sosyal bilimlerde nitel araştırma yöntemleri. Ankara: Seçkin Yayıncılık.

Yolcu, H. ve Bayram, A. (2016). Eğitimde teknoloji kullanımı: Fatih projesine eleştirel bakış. Abant İzzet Baysal Üniversitesi Eğitim Fakültesi Dergisi, 16 (4), 2111-2143.

Yorganc1, S. ve Terzioğlu, Ö. (2013). Matematik öğretiminde akıllı tahta kullanımının başarıya ve matematiğe karşı tutuma etkisi. Kastamonu Ĕgitim Dergisi, 21(3), 919-930.

Zhao, Y. ve Hoge, J. D. (2005). What elementary students and teachers say about social studies. The Social Studies, $96(5)$, 216-221. 